Surgeons, since it applied to "London, and ten miles round," and was not required by law for persons beyond the limits alluded to. Such, indeed, is my own case, having studied the full period, and commenced practice some twenty years ago, since which time I have had a large medical and surgical practice, have lectured occasionally on anatomy, have performed almost every capital operation, over and over again, and am frequently appealed to in cases of difficulty and danger by my more diplomatic brethren. I am, of course, anxious to know how far the Act wil provide for such cases, and also, whether the personal honour and financial interests of such men as $I$ have described are to be sacrificed at the shrine of class interest and government patronage for such appears to me to be the prizcipal features of the Bill under consideration. Yours,

\section{A General Practitioner,}

Cheshire, Sept. 29. 1844

Of more than twenty years' standing.

\section{THE HERMAPHRODITE MEDICAL MEETINGS.}

To the Editor.-Sin, At the twenty-eighth chapter, according to " Enfield's Speaker," and the 57th page, you will find it thus written:-

$$
\begin{aligned}
& \text { I hold it, therefore, wisest and most fit,", } \\
& \text { That, life to save, we leap into the pit." }
\end{aligned}
$$

Such, Sir, is the sum and substance of the advice tendered by the Worcestershire bell-wether to his obsequious Derbyshire flock on the 14 th inst. - advice so sage that they cannot choose but follow it. Never did any set of men seem more desperately bent upon self-destruction.

It is an old saying, that " coming events cast their shadows before them," and I forewarn you that your office of coroner, whatsoever it may have hitherto been, will shortly be no sinecure. Take my advice, and apply forthwith to the " polite" Secretary of State for the Home Department for assistance. But what are your juries to do? They will be sorely puzzled to decide upon their verdict, whether it shall be "non compos" or "felo-de-se." I hope, for the sake of the poor babes and widows, the former.

At almost all the meetings which have been recently held upon the subject of Sir James Graham's bill, I find the hearts of my medical brethren "overflowing with gratitude" to the worthy baronet for a measure which you have denounced as, and incontrovertibly demonstrated to be, subversive of their interests; and at these same meetings, with a beautiful simplicity, to be equalled only by its beautiful consistency, I find them passing unanimous rotes of thanks to you, "for your able, consistent, and energetic advocacy of their rights and privileges." Are these gentlemen such egregious blockheads that they cannot perceive how com pletely they are stultifying their own proceedings? Or have they the consummate folly to imagine that they can impose either upon you or Sir James Graham, by this piece of bi-facial cajolery?

Much credit is given to Sir James Graham for " good intentions." It is a saying of a certain great divine, (Baxter, I think, that " hell is paved with good intentions;" and, for anything, know to the contrary, the cranium of Sir James may be similarly tesselated. If it be so, it would be well to subject it to the pro-

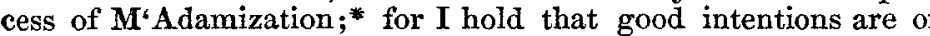
but little value unless they be followed by good actions. Of Sir James Graham, personally, I know nothing, therefore I cannot reasonably be suspected of being influenced by personal feeling. In the walks of private life he is, I dare say, very amiable, very estimable, very virtuous, "and all that sort of thing," but as a public character he stands the lowest, in my estimation, of any member of the House of Commons. If I have been correctly in formed, he is an apostate from those political principles which he professed with earnestness, and maintained with ability, for many, many years. Sudden conversions may be genuine, and the convert's intentions may be not only good, but pure also, and probably Sir James purposed good to-himself, and was converted from ultra-radi-whigism to ultra toryism, for the pure object of self-aggrandizement; but I have ever considered that the man who, for power or pelf, renounces his political creed, is scarcely so respectable a character as the Jew or Christian who abjures his religious faith to escape the infliction of the bastinado. But we have heard enough of Sir James's " good intentions;" let us now analyze two or three of his good actions, and we need not go far back to find them.

Act 1.-The members of the Provincial Medical Association,

* Mental, of course. I would not for the world have it for one moment supposed that I wish his brains to be literally knocked out : his great pro totype, however, Sir Robert Peel, was dreadiully alarmed at a less direct insinuation, in one of Mr. Cobden's speeches. through their delegates, respectfully solicited a conference with him. He (very politely, according to Dr. Hastings) slammed the door of the Home-office in their faces.

Act 2.- The great body of the profession prayed that no new charter might be granted to any medical corporation until their grievances had been investigated. $A$ new charter, through the instrumentality of Sir James Graham, was procured for the College of Surgeons-a charter which put it in their power to degrade and insult nineteen-twentieths of their members.

Act 3.- Sir James Graham introduced a bill into the House of Commons, ostensibly "for the better regulation of the medical profession," but, covertly, for its destruction. "Oh! rare James Graham!" Blessings upon thy "good intentions" as well as upon thy good actions; the latter so like the former that we know not for which to be most grateful. Let us not merely go upon " bended knees," but fall down and worship the image which we have set up. We asked thee for hread, thou didst give us a stone; we asked thee for a fish, thou didst give us a serpent; we asked thee for protection, thou didst take from us even that which we had.

If it were necessary, I could write much more; but you, Sir, have so fully, so clearly, so ably, so forcibly, exposed the hollowness, the selfishness, the hypocrisy, as well as the destructive tendencies, of this treacherous measure, that I shall only further beg to offer for your acceptance the sincerest thanks and best wishes of, Sir, your obedient servant,

No JANUS, Suffolk, Nov. 20, 1844 .

\section{INFIRMARY FOR THE CURE OF CLUB FOOT, \&c.}

To the Editor.-Srn, I have read with surprise the letter of “A Constant Reader," in The Lancet of Saturday, the 16th instant, and I trust you will oblige the committee by inserting my official contradiction of the statement therein put forth.

The Earl of Arundel and Surrey, Dr. Stromeyer, and Mr. Amos Swaisland, have not resigned; nor is the latter a Vice-President; and though the Earl of Eldon and the Messrs. Heisch have, it was not alleged to be on account of " bad management" by the committee; nor was it so, but by reason of circumstances not originating with the committee, and in respect of which they had only a limited power. The retirements which have taken place, and every occurrence connected therewith, and with the general affairs of the charity, have been laid by the committee (who never intended to keep them secret) before a full court of Governors, at which Philip Hanbury, Esq., V.P., presided; and a resolution of approbation and confidence was unanimously roted to the committee. It is important I should also mention, that under the management of the existing committee, a sum of upwards of five hundred pounds more than the gross receipts of any whole preceding year, has been collected since February last; the debts of past committees have been paid, (leaving a balance at the bankers, ) and a much greater number of both In and Out patients relieved, than during the entire of any former year-though all who apply cannot be admitted, in consequence of the funds being still insufficient. I will not occupy your valuable columns further, than by expressing a sincere hope, that the injury which it is the object of "A CONSTANT READER," by his anonymous mis-statements, to do to this very useful and humane institution, will be averted. I have the honor to be, Sir, your very obedient servant,

H. Gillett Gridley, Hon. Sec.

The Orthopœdic Institution, 6, Bloomsbury Square. November 22nd, 1844 .

25th Nov.-Permit me, (by way of P.S. to my letter of the $22 \mathrm{nd}$,) in answer to the further statement of "A Constant READER," dated 19th November, appearing in your last number, to deny that he had " just seen" the resignation of Mr. Serjeant Adams, inasmuch as it was in my possession several days prior to, and on, the 19th instant; and $I$ am certain was not seen by any one save the committee, until after that date. But if the statement of “ A ConstaNT READER" were true, he is still guilty of mis-representation, because it is apparent, on the face of such resignation, that the Serjeant retired with much regret, and not on account of " bad management."

\section{APOTHECARIES' HALL, LONDON.}

NA Mas of gentlemen who obtained certificates to practise as apothecaries in England and Wales, 21 st Nov. 1844:-John Rider, Crudgington, Salop : Charles Joseph Tomkins, Abingdon, Berks ; Abraham Hoskins, Wood Villa, Staffordshire; Frederick Gaunt, Aloechurch, Worcestershire; Henry Smith Palmer; Thomas Watts, Frampton, Gloucestershire; Leopold Beharrill Fox, Teignmouth, Devon. 